\title{
The Utilization of Instructional Technologies to Augment Traditional Instructional Strategies Within Online Undergraduate Entrepreneurship Programs
}

\author{
Ellen M. Raineri \\ Pennsylvania State University \\ Amy Kuntz \\ Pennsylvania State University \\ Jessica Resig \\ Pennsylvania State University
}

Researchers have categorized the methods used to teach entrepreneurship in a face-to-face delivery mode. However, little research has examined methods used for teaching entrepreneurship online. Accordingly, this paper surveys faculty and program chairs at universities that offer online entrepreneurship courses in order to establish a baseline of instructional strategies used within online entrepreneurial education. Since extant literature on effective entrepreneurial teaching methods emphasize the inclusion of entrepreneurship exercises to be experiential and creative, the authors build upon their survey baseline by suggesting five typical activities from the online canon and re-purpose them to increase the experiential nature of such exercises.

Keywords: entrepreneurship education, instructional strategies, experiential learning, online education, instructional technologies, collaborative learning, authentic learning, online learning, asynchronous online learning, educational technologies

\section{INTRODUCTION}

Entrepreneurship has long been recognized as an important factor for economic growth and innovation (Van Praag \& Versloot, 2007). As such, institutions of higher education within the United States have focused efforts on offering programs to meet the needs of future entrepreneurs. The number of entrepreneurship courses offered by U.S. higher education institutions grew from 250 in 1985 to over 5,000 in 2008 (Brooks et al., 2008). Today, the National Center for Education Statistics reports that 260 bachelor's programs in entrepreneurship are offered nationwide (National Center for Education Statistics, 2020). As this focus on entrepreneurship continues, the United States Department of Commerce has identified higher education institutions as critical partners in nurturing regional economies and supporting sustained growth in entrepreneurship (Case, Coleman, \& Deshpande, 2013). 
Concurrently, higher education institutions have experienced steady growth in distance education. In fall of 2017, 5.5 million undergraduate students (nearly one-third of all undergraduates) took distance education courses, with 13 percent enrolled in exclusively distance education courses (McFarland et al., 2018). The National Center for Education Statistics' Integrated Postsecondary Education Data System (IPEDS) data for 2018-2019 indicate that 29.2\% of U.S. institutions offer undergraduate programs via distance education. Of the 260 bachelor's degrees in entrepreneurship offered in the U.S., 25 programs are offered in a fully-online format (College Navigator, 2020).

Experiential learning is regarded as an important pedagogical strategy for teaching entrepreneurship (Mandel \& Noyes, 2016; Pittz, 2014). However, instructors teaching online courses face unique environmental and time-related constraints that may impact how they engage with students. Though the online learning environment lends itself well to the use of innovative technologies, "technology by itself does not yield the greatest impact on learning; it does so when it is embedded in a scaffolding of support for learners and instructors" (Brown et al., 2020, p. 13). Utilizing technology-facilitated instructional strategies that situate students' learning within the context in which it will be used creates more authentic, robust learning experiences (Herrington, Reeves, \& Oliver, 2013). While the importance of these types of strategies is well-recognized in entrepreneurship education (i.e. Haase \& Lautenschläger, 2011; Mwasalwiba, 2010), little is known about how these strategies are being employed to teach entrepreneurship online. The parallel growth of online learning and entrepreneurship programs warrants an exploration of the instructional strategies being utilized to teach entrepreneurship in an online environment, as well as the creation of technology-infused entrepreneurship exercises designed to offer authentic, experiential learning.

\section{LITERATURE REVIEW}

\section{Goals of Entrepreneurship Education}

Within undergraduate entrepreneurship major or minor programs, entrepreneurship education has numerous educational directions or goals. One of the goals focuses on teaching students how to be a small business owner which can be through the path of starting one's own business, purchasing an existing business, purchasing a franchise, or purchasing a patent (Kikirzyu, 2013). Another educational goal focuses on preparing students be an intrapreneur - exhibiting the characteristics of an entrepreneur within an existing organization - to develop a new product/service or to make an existing product or service more innovative. The later initiative is often part of corporate entrepreneurship (Pinchot III, 1985). Another educational goal of entrepreneurship education is to assist students in creating an entrepreneurship mindset, that is, to recognize opportunities that can be pursued with no thought for resources that are not within their control (Kirzner, 1973; Laukkanen, 2000; Neck, Neck, \& Murray, 2017; Stevenson \& Jarillo, 1990). Another educational goal is to assist students with developing skills for social entrepreneurship or social venturing which addresses social, environmental, or cultural problems resulting in a type of social transformation (Alvord, Brown, \& Letts, 2004; Yujuico, 2008). Last, an entrepreneur's personal skills can be a focus for entrepreneurship education (Mwasalwiba, 2010).

\section{Subject Areas of Entrepreneurship Education}

Numerous subject areas support the aforementioned goals. Each can be the focus of a single course or several can be combined into a course. Subject areas are as follows:

1. Technology commercialization projects (Duval-Couetil, 2013)

2. Financing (Mwasalwiba, 2010).

3. Business functional areas (i.e. marketing, accounting, IT) (Mwasalwiba, 2010; Ronstadt, 1990)

4. Business planning (Gartner \& Vesper,1994; Haase \& Lautenschläger, 2011; Honig, 2004; Okudan \& Rzasa, 2006; Souitaris, Zerbinati, \& Al-Laham, 2007)

5. Technology commercialization projects (Duval-Couetil, 2013)

6. Small business management (Mwasalwiba, 2010)

7. Risk management (Mwasalwiba, 2010) 
8. Family business (Mwasalwiba, 2010)

9. Franchising (Mwasalwiba, 2010)

10. Idea generation (Mwasalwiba, 2010)

11. Managing growth (Mwasalwiba, 2010)

12. Organization and team building (Mwasalwiba, 2010)

13. Creativity (Boyle, 2007)

14. Soft skills like creativity, networking, time-management, negotiation, ambiguity acceptance, problem solving (Gibb, 1996; Haase \& Lautenschläger, 2011; McMullan Gillinm, 1998; Rae, 1997; Ronstadt, 1990)

\section{Entrepreneurship Education Methods}

The literature describes a variety of active and passive methods used by faculty members to teach entrepreneurship as follows:

1. Business plan pitches (Duval-Couetil, 2013)

2. Business simulations (Mwasalwiba, 2010)

3. Managing growth (Mwasalwiba, 2010)

4. Case studies (Haase \& Lautenschläger, 2011; Mwasalwiba, 2010)

5. Company field trips (Haase \& Lautenschläger, 2011)

6. Entrepreneur interviews ((Haase \& Lautenschläger, 2011)

7. Guest speakers (Haase \& Lautenschläger, 2011; Mwasalwiba, 2010; Powell, 2013)

8. Incubators/start own business (McMullan \& Gillinm, 1998)

9. Internships (Duval-Couetil, 2013; Haase \& Lautenschläger, 2011)

10. Lectures (Haase \& Lautenschläger, 2011; Mwasalwiba, 2010;)

11. Mentors (Powell, 2013)

12. Discussions and team projects (Mwasalwiba, 2010)

13. Reading (Haase \& Lautenschläger, 2011)

14. Real world experience - i.e. consulting (Peterman \& Kennedy, 2003)

15. Simulations (Haase \& Lautenschläger, 2011)

\section{Conflicting Considerations Faced by Entrepreneurship Faculty}

When choosing a method(s) for teaching entrepreneurship, faculty members may be faced with challenges since conflicting considerations exist. Powell (2013) addresses four. First, faculty members may consider the challenges of including uncertainty/ambiguity. Having a tolerance for uncertainty is an important aspect of an entrepreneur (Arpiainen \& Kurczewska, 2017). Knight (1921) further postulates through Knightian Uncertainty that unlike risk, uncertainty is not measurable or quantifiable; uncertainty also cannot be managed. Last, a known distribution of probability exists with risk (i.e. pulling a queen from a deck of cards -4 queens in a deck of 52 cards). With uncertainty, the distribution of probability is unknown. Despite this challenge, numerous advantages exist if entrepreneurs have a tolerance for uncertainty. Accordingly, some competitors may be uncomfortable with uncertainly and therefore pursue fewer opportunities. As a result, because of the high level of unknowns, higher possibilities may also exist (DeMers, 2017).

The uncertainty that entrepreneurs must navigate in real life situations is often starkly contrasted with the structure and pedagogical methods found in educational programs designed for student success. Challenging the status quo may be difficult (Jeffrey \& Dean, 2006; Sexton,1984). The pedagogy and design of business courses is often structured as dictated by the administration which leaves little room for students to navigate uncertainty. Faculty may routinely communicate to students what they need to know and why such knowledge is important. Syllabi may contain specific due dates or detailed instructions for projects/papers that are broken into step-by-step pieces with delineated due dates and detailed instructions. Lecture notes or publisher's slides are given to students prior to class, removing the need for deep reading. Additionally, students may be resistant to an unstructured syllabus (DeMers, 2017; Sexton, \& Bowman, 
1984). A final dilemma of including uncertainly involves grades. Powell (2013) notes that students who typically earn higher grades tend to score lower when pedagogy loses elements of structure.

Second, faculty may consider the challenge of boosting students' confidence. Faculty may debate if they should provide feedback that collectively boosts self-efficacy even if their students do not have the appropriate level of knowledge and experience to be a successful entrepreneur at this early stage of their career. Still, few students may have the applicable knowledge and skills (i.e. being raised in a family business, working part-time for a start-up company), so faculty may choose to individualize to bolster selfconfidence. However, this may be difficult to do in large attendance classes (DeMers, 2017).

Third, faculty may be challenged by the decision to offer general versus applied content to a class of entrepreneurship students. For example, faculty may offer general small business management topics but may not be specific enough for some students. For example, consider the student who has the goal to be a real estate broker. Such specific knowledge may not have value for the majority of the class. Additionally, such specific knowledge, in real estate or in other specific entrepreneurial occupations, may be difficult for the faculty to have such subject matter fluency for applied content. Even with the inclusion of subject matter guest speakers, variety and quantity of such individuals are challenges with large classes. Last, even with the incorporation of student self-study, assessing students can be difficult with large class sizes (DeMers, 2017).

Fourth, faculty may face the dilemma of determining if they should include best practices of successful entrepreneurs to encourage students to imitate such entrepreneurs. DeMers (2017) cautions that if students imitate success, they may miss out on their own discovery process which facilitates learning. Although an approach may combine letting students try on their own and then showing examples of others' successes, a larger class size may thwart such effort.

\section{Teaching Entrepreneurship Online}

Entrepreneurship faculty teaching courses online face the additional challenge of being separated from learners physically, and often by time, as students access courses at their convenience. Gayton and McEwen (2007) found that online learners benefit from clearly explained assignments, the use of rubrics, regular and timely feedback, and a variety of online assessments, including projects, portfolios, discussion forums, selfassessments, and peer evaluations (p. 125). However, this degree of structure may be at odds with the call for experiential, unstructured, and risk-based learning that is valued within entrepreneurship education (Mandel \& Noyez, 2016).

Accordingly, this paper identifies the types of instructional strategies used within nationally ranked online entrepreneurship programs and proposes new instructional technology exercises to improve experiential pedagogical practices in this space that can also give students more opportunities to practice navigating uncertainty.

\section{METHODOLOGY / RESEARCH DESIGN}

In the literature review, we found a mutual consensus about the importance of the types of instructional strategies currently being employed overall in US undergraduate entrepreneurship courses that did not specify the course modality. Therefore, the authors decided to examine if the extant literature contained any review of the types of instructional strategies instructors of undergraduate online entrepreneurship courses report using in their courses as well as if the instructional strategies reported in online courses reflect established best teaching practices.

Finding no such review, the authors decided to conduct a national survey of instructors teaching online entrepreneurship undergraduate courses to explore the types of instructional strategies being utilized in their courses. This information could then help to guide recommendations for improvement in all modalities of instruction and help to establish a new line of ongoing research in this area. 


\section{Sample}

To obtain a wide representation in our sample, recruits were identified from nationally ranked U.S. higher education institutions that offer undergraduate online entrepreneurship courses. The details are as follows:

- Possible recruits were identified from business programs that teach entrepreneurship courses and entrepreneurship programs as listed from the US News and World Report Best College Rankings Online Bachelor's Degrees and Programs (Top 20), US News and World Report Best College Rankings Online Bachelor's Degrees and Programs Best Undergraduate Business Programs Rankings, US News and World Report Best College Rankings Online Bachelor's Degrees and Programs Best Undergraduate Entrepreneurship Programs, and The Princeton Review/Entrepreneur Magazine Top 25 Undergraduate Schools for Entrepreneurship. In order to identify program chairs and faculty of entrepreneurship courses from these institutions a detailed investigation for each potential program was done via their course scheduling systems, recommended academic plan for each program, and information provided at their institutional and program level websites. The results were then documented to include the program, entrepreneurship courses, teaching faculty and program chairs for the associated programs.

- An invitation to participate was emailed to online entrepreneurship undergraduate faculty and program chairs. Those who accepted the invitation to participate were then sent the survey with consenting information attached. The survey introduction letter is included in Appendix A.

\section{Instrument}

The survey took participants approximately fifteen minutes to complete. The questions included overview and instructional strategy information for each entrepreneurial course that a participant has taught. For each course, logistic questions such as type of student population, course format, course name, course number, core concepts taught in the course as well as if the course was an elective or required course for the major were included. This was followed by the focus on frequency of use for various instructional strategies in the entrepreneurial area along with an open-ended question geared towards soliciting more instructional strategies used.

Questions then drilled down into each course by having participants describe barriers, obstacles, or challenges in offering the instructional strategies in an online format. This process was then repeated for any additional courses the instructor taught, up to five courses in total. Demographic information was also collected. The total number of questions was based upon how many entrepreneurial courses an instructor taught. For those who taught one entrepreneurial course, participants completed eight open-ended questions and eleven closed-ended questions for a total of nineteen questions.

\section{RESULTS}

The response rate from the exploratory study was close to $1 \%$. Respondents indicated that most courses were in the upper intermediate or capstone level for 3rd and 4th year undergraduate students. All courses in the reporting were elective courses.

The online entrepreneurship courses described were varied and represented important topics covered in any entrepreneurship program as follows: Entrepreneurship and Small Business Management, Entrepreneurial Marketing, Entrepreneurial Finance, Franchising, and Special Topics in Entrepreneurship: and New Venture Creation. Last, key concepts within those courses included Product Development, Entrepreneurial Mindset, Entrepreneurial Finance, Innovation, Creativity, Customer Development, Sales/Marketing, Crowdfunding, Digital Commerce, Social Entrepreneurship, Customer Service, Business Process, Business Planning, Feasibility Analysis, Brand Management, and Customer Development.

\section{Entrepreneurial Experiences Included in Courses}

Respondents described what they considered to be the most important experiential activities in their courses comprising two categories - those completed within the classroom as well as those completed 
outside the classroom. For example, activities internal to the classroom included having online guest speakers, providing students with videos, walking students through steps of a business plan, incorporating creativity exercises, prototyping, and mentoring students. Activities external to the classroom involved students working with entrepreneurs and meeting with customers. Last, one respondent candidly noted a lack of experiential experiences stating, "This class has little to offer by way of experiential education."

\section{Barriers to Using Entrepreneurial Instructional Strategies}

Respondents stated a lack of time and obtaining administrative approval as barriers, as well as class size which respondents indicated can be problematic at both extremes - too many students or too few students to foster participation in an entrepreneurial learning activity.

\section{Instructional Strategies Used}

The list of all types of instructional strategies used within the courses are summarized below in TABLE 1 by frequency of use.

TABLE 1

\section{INSTRUCTIONAL STRATEGIES USED BY FACULTY}

\begin{tabular}{|l|l|}
\hline Type of Instructional Strategy & Percentage Integrated on Regular Basis \\
\hline Quiz & $\sim 85.72 \%$ \\
\hline Case Study & $\sim 71.43 \%$ \\
\hline Problem-Based Learning & $\sim 57.14 \%$ \\
\hline Working with an Entrepreneur & $\sim 57.14 \%$ \\
\hline Exam & $\sim 42.86 \%$ \\
\hline Business Simulation Game & $\sim 28.57 \%$ \\
\hline Lecture / Direct Instruction & $\sim 28.58 \%$ \\
\hline Setting Up a Business & $\sim 28.57 \%$ \\
\hline Business Plan & $\sim 14.29 \%$ \\
\hline Business Visits / Field Trips (virtual or in person) & $\sim 14.29 \%$ \\
\hline Consultancy Project & $\sim 14.29 \%$ \\
\hline Counseling / Mentoring & $\sim 14.29 \%$ \\
\hline Guest Speaker & $\sim 14.29 \%$ \\
\hline Practical Training / Internship & $\sim 14.29 \%$ \\
\hline
\end{tabular}

\section{DISCUSSION}

Numerous uses of instructional strategies by the survey participants align with the extant literature. For example, Zotov, Frolova, Prasolov, and Kintonova (2020) state that the use of problem-based learning and case studies are most commonly used within entrepreneurship education as was depicted in this study. Many positive outcomes are experienced by students when using case studies such as enhanced analytical skills, creative exploration, self-confidence, subject interest, retention, enjoyment, and application (Forrester, 1981; Penn, Currie, Hoad, \& O’Brien, 2016).

Evaluating the instructional strategies provided in the survey, the authors found that many are actionoriented and are commonly used within entrepreneurship education (i.e. interviewing customers or engaging in simulations). Additionally, some activities are more passive (i.e. listening to lectures, podcasts, or videos). Although such instructional strategies may be effective in contributing to learning outcomes, they do not align with the important goal of having the teaching of entrepreneurship be more entrepreneurial in nature, meaning that students gain the skills, knowledge, and mindsets needed to become successful entrepreneurs through experiential learning - and especially to unsettle entrepreneurship education, an idea that has been advanced by Berglund, Hytti, and Verduijn (2020). 
To build a bridge between traditional forms of teaching and more experiential forms, the authors provide five exercises that utilize technology-facilitated instructional strategies to unsettle entrepreneurship education and situate students' learning within the context in which it will be used, thus creating more authentic, experiential learning experiences (Herrington, Reeves, \& Oliver, 2014).

\section{INSTRUCTIONAL TECHNOLOGY EXERCISES WITHIN ONLINE UNDERGRDAUATE ENTREPRENEURSHIP EDUCATION}

The traditional instructional strategies from the results can serve as a baseline for the types of experiential instructional strategies currently in use. Building upon them, five instructional technology exercises were developed to further support experiential learning within online entrepreneurship programs. The entrepreneurship areas for these exercises include bootstrapping, competitive intelligence, location analysis, reflection upon entrepreneurship potential, and market research; the exercises are examples of the instructional strategies of problem-based learning, business plans, and setting up a business that correlate to the higher percentage strategies of the survey results.

\section{Exercise 1: Bootstrapping}

Instructional Strategies

Business plan, problem-based learning, and setting up a business.

\section{Importance of Entrepreneurship Exercise}

Bootstrapping is quite important for entrepreneurs since it may be difficult to raise enough capital in conventional ways. Accordingly, entrepreneurs commonly engage in creative ways to acquire necessary resources for their businesses (Harrison, Mason, \& Girling, 2004). Resources not only focus on capital. Rutherford (2015) documents creative strategies for other resources such as joining bartering clubs, utilizing fractional executives who share their time with several organizations, and avoiding high price office rentals - citing the example of Under Armour's CEO, Plank who initially sold products from his car. In a study of 91 start-up ventures, Malmström (2014) has also found creative strategies that include personal financing, bartering, borrowing equipment, purchasing used products, paying supplies after a service/product sold, and hiring temp workers.

\section{Example of Traditional Entrepreneurship Exercise}

In a general entrepreneurship course that involves the creation of a business plan, an assignment may focus on asking students or student teams to define specific bootstrapping strategies that would work for their business or service (i.e. engaging in types of bartering, using services from fiver.com, obtaining assistance from internships, obtaining advice from SBDA/SCORE, purchasing particular used products, marketing by generating free PR ideas, and more. For each bootstrapping strategy, students would have to be specific and detailed. For example, students could include their written mock PR article that they would use for free marketing. In another example, students could include detailed pricing, office size, and shared services if they leased space at a low-cost incubator center.

\section{Discussion of the Technology Enhanced Entrepreneurship Exercise}

To assist with visual communication, students can be guided to take key aspects of their identified bootstrapping strategies to create an infographic; an example is at http://bit.ly/bootstapping_infographic with the top half shown in FIGURE 1. This infographic will be utilized as a visual presentation of the bootstrapping strategies that work with their business idea/service along with the initial steps for each activity. Infographics are combinations of data / information with visual elements as part of an overall theme to convey a message through visual storytelling. The general benefit of utilizing graphics is it helps tell information in an organized way so that others can see the relationship between components. Through these components, those viewing the infographic have been shown to have a better understanding of the content Baglama et al. (2020). 


\section{FIGURE 1 \\ CROWDFUNDING INFOGRAPHIC}

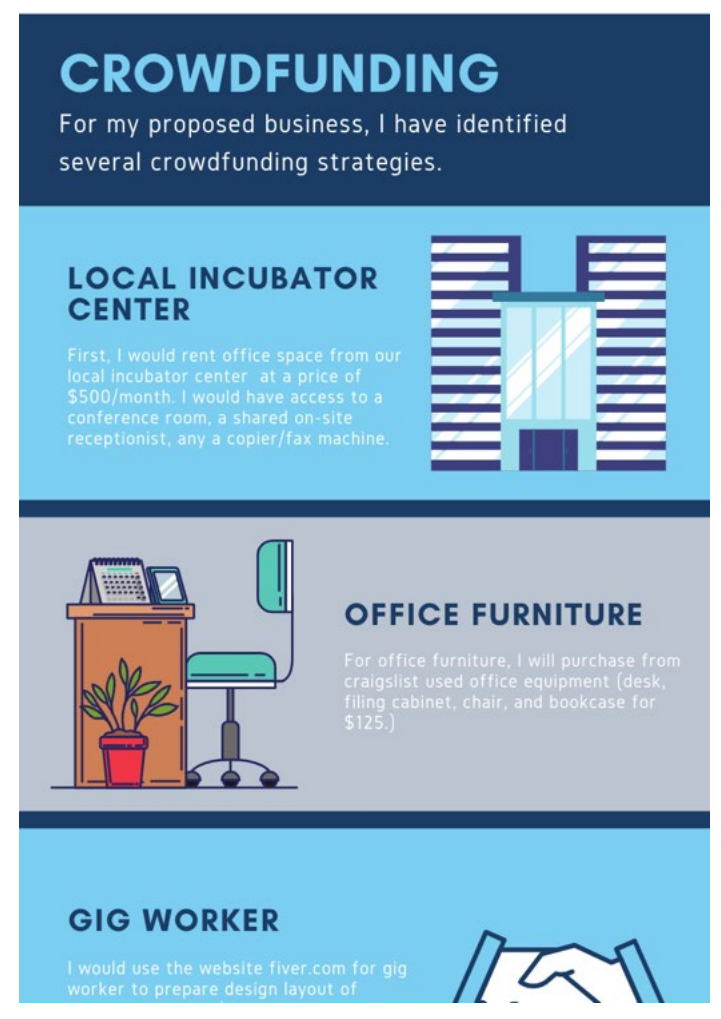

Exercise 2: Competitive Intelligence

Instructional Strategies

Business plan, problem-based learning, and setting up a business.

Importance of Entrepreneurship Exercise

Engagement in competitive intelligence permits individuals to examine aspects of internal, external, and competitive environments in order to optimize their decision making which is especially important for start up companies (Tahmasebifard, 2018). The engagement in competitive intelligence by entrepreneurs is especially important since these small and mid-size firms are often considered to be more vulnerable (Tarek, Adel, \& Sami, 2016). An example of a competitive intelligence framework is SWOT (strengths, weaknesses, opportunities, threats) analysis because it incorporates internal and external evaluations (Bose, 2008).

\section{Example of Traditional Entrepreneurship Exercise}

After students have identified a type of business they would like to start, they can be asked to select a competitive analysis model to apply to their business when developing a business plan or in a separate problem-based learning activity. Students can be asked to provide a summary of strengths/advantages and weakness/limitations of the model they selected and to explain the process steps of that model. Last, students can be asked to apply that model to their business. Results can be shared in numerous ways such as a paper or a presentation.

\section{Discussion of the Technology Enhanced Entrepreneurship Exercise}

To integrate asynchronous presentations that allow for peer-feedback on particular slides, VoiceThread can be utilized in a contemporary methodology that focuses on the connectivism theory. Although the 
VoiceThread tool can be utilized in many different ways, in this particular use case, students would upload and edit PowerPoint presentations within their VoiceThread account. They would then submit the link to the faculty member and fellow students for peer feedback. These links would allow them to view and hear the presentation along with the ability to make text, audio, or video comments on any given slide including the ability to annotate on the slide as part of the comment. As shown in FIGURE 2, for slides with comments on them, it is typical to have a student photo associated with it along with a visual indicator of the percentage bar at the bottom to indicate the need for playback and estimation of the length of the comment. Due to the wide range use of VoiceThread, the design of the assignment has a large impact on how VoiceThread can be utilized for assessment. With that in mind, it has been found that when VoiceThread is utilized as an assessment tool, students appreciate the contemporary assessment method, the process was fairly intuitive to quicky create high quality presentations, and the interactive feedback by peers and the faculty was a valuable asset (Taleo, Reedy, \& Isaias, 2019).

FIGURE 2

\section{VOICETHREAD OF ENZO'S PIZZERIA PRESENTATION}

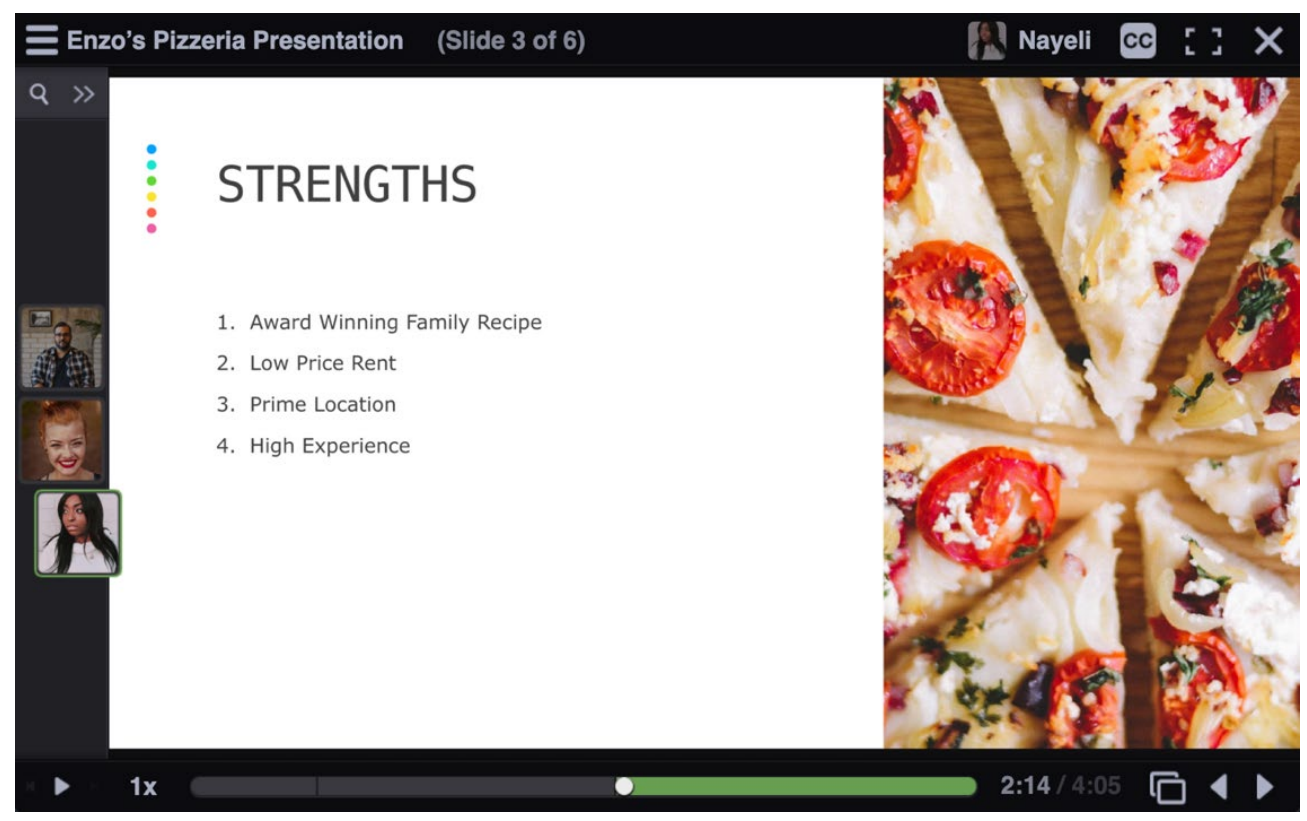

Exercise 3: Location Analysis

Instructional Strategies

Business plan, problem-based learning, and setting up a business.

\section{Importance of Entrepreneurship Exercise}

The choice in location is important in order to maximize the attraction of customers' purchases and to possibly avoid the high expense of a commercial lease for a property's location that is inadequate. Hence, entrepreneurs should query, "Why this location" for physical or online presence and can be aided by exploring aspects such as traffic count, market demographics, ease in finding employees, and surrounding competitors (More Business, 2020). Additionally, Speade (2020) affirms the adage of the importance of "location, location, location" and recommends entrepreneurs check zoning, traffic pattern, traffic generators (i.e. retailers, schools, hospitals, hotels), car/foot traffic, lease terms, parking spaces, access to public transportation, and expansion possibilities. 


\section{Example of Traditional Entrepreneurship Exercise}

Entrepreneurship students can be asked to include a location analysis for their product or service business when developing a business plan or in a separate problem-based learning activity. The instructor can provide some standard aspects for students to research such as zoning, traffic count, number of parking spaces and can ask students to supplement choosing other aspects of location analysis that are important to consider for their specific business (i.e. amount of seasonal business or traffic generator businesses). The results can be shared in a paper or presentation.

\section{Discussion of the Technology Enhanced Entrepreneurship Exercise}

To visualize the location analysis, the creation of a learner-generated Google My Maps allows the learner to create a set of locations/places of relevance to them. This includes adding a point of interest with a visual marker that can be changed to several different icons/colors along with the ability to make notes about the location. By creating a map of the top three locations along with the data for comparison, it allows for visual connections of the three locations in a geographical manner. In addition, if chosen to have this information be publicly available and inviting external members of the class to review their analysis, connected learning occurs which has the benefit of blurring the boundaries of public and private spaces for learning that can bring new perspectives (Kek, Megan, \& Huijser, 2017). As seen in FIGURE 3, a quick visualization of the three locations can show perspectives of location. Then when clicking on a location, the granular detail about the logistics can be reviewed and compared to the other locations.

\section{FIGURE 3 \\ GOOGLE MY MAPS: \\ OVERALL VIEW OF LOCATIONS AND DETAILED VIEW OF LOCATION A}

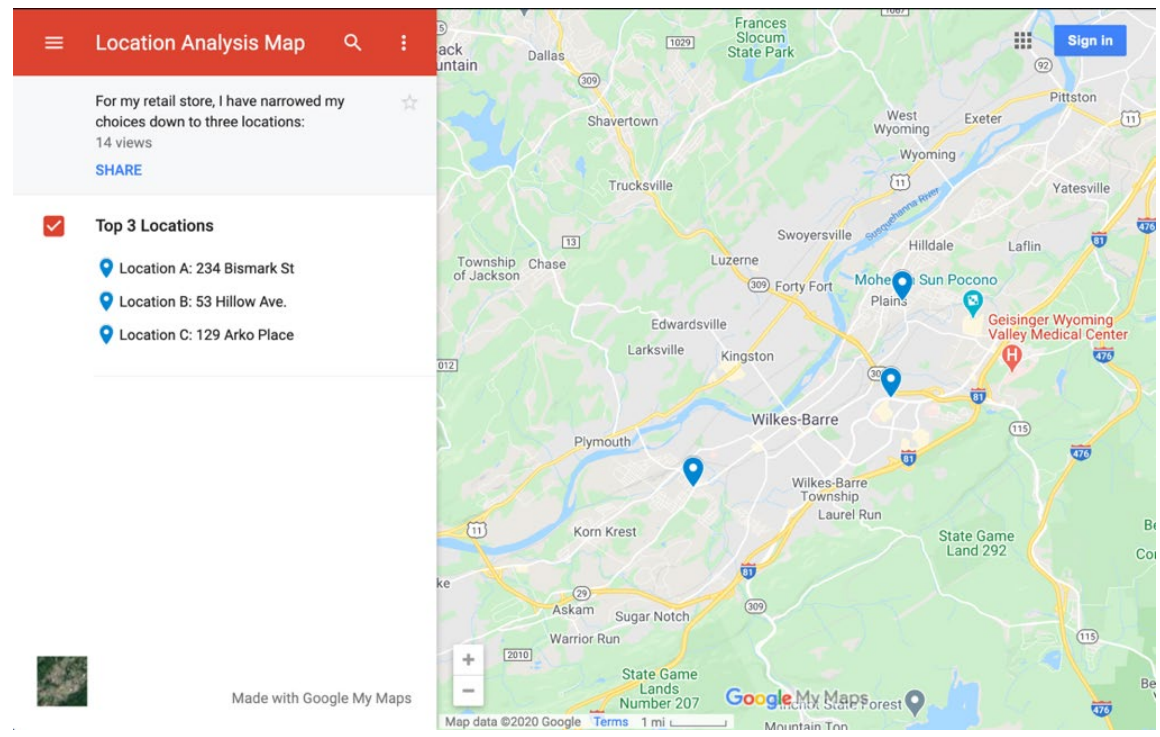




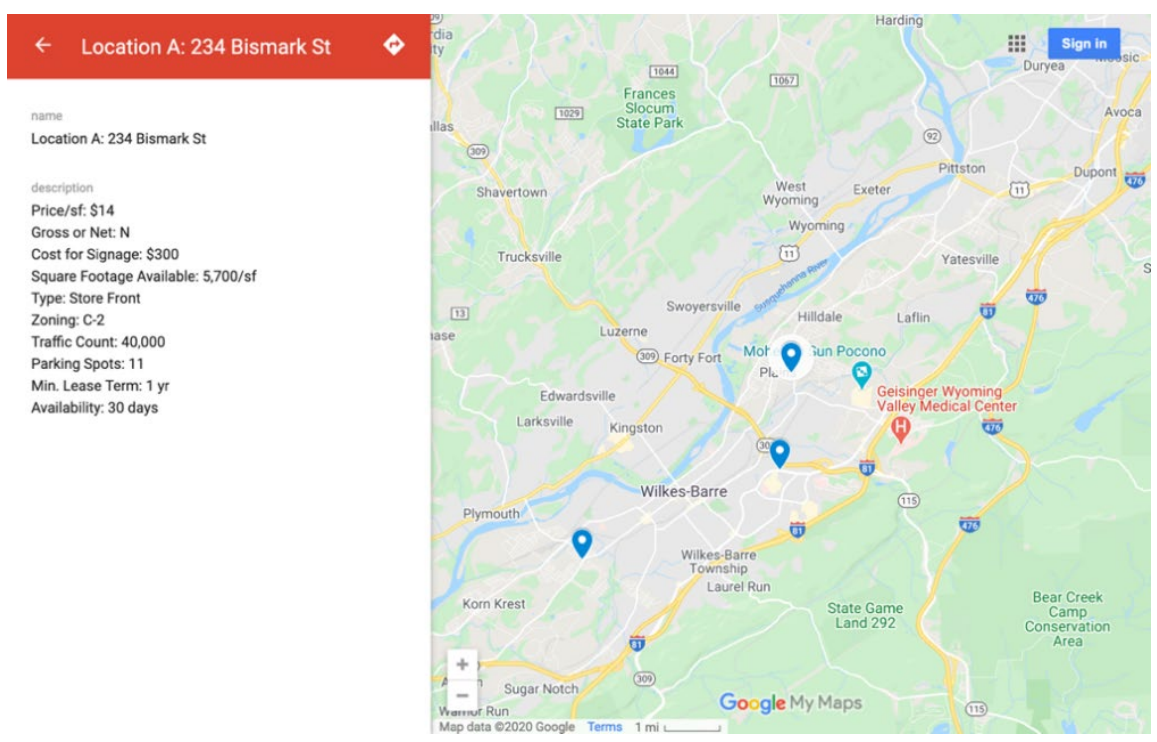

\section{Exercise 4: Reflection Upon Entrepreneurship Potential}

Instructional Strategy

Problem-based learning (reflection).

\section{Importance of Entrepreneurship Exercise}

When individuals understand different aspects of themselves and their resources within a career of entrepreneurship, those individuals can know apply their strengths and advantages while seeking other individuals and resources to supplement weaknesses and lack of resources. For example, individuals' knowledge and application of entrepreneurial traits can be beneficial with managing a new business as well as in later stages of growth with some key traits being creativity, self-efficacy, internal locus of control, and achievement motivation (Imran, Ahmed, Streimikiene, Soomro, Parmar, \& Vveinhardt, 2019).

\section{Example of Traditional Entrepreneurship Exercise}

Numerous assessments exist for students to determine aspects of their entrepreneurial potential. Small Business Association (n.d.) has developed an Entrepreneurship readiness assessment. The 25 questions probe the areas of personal qualities, personal conditions, as well as skills and expertise. The assessment developed by Infusion Soft (2020) assists individuals to determine the specific type of entrepreneur they are by probing an individual's desire for independence, creative expression, repeated entrepreneurship, and more. The quiz from Humanmetrics (2020) helps individuals to identify aspects like entrepreneur type and optimal size of a business. The assessment developed by Christensen (2004) begins by examining entrepreneurial traits of a student compared to a model entrepreneur. Next, students examine their three lowest scored traits and identify steps for improvement as goals. Students are then asked to identify individuals who can hold them accountable for meeting those improvement goals. Last, students form an action plan with dates to accomplish those goals. Utilizing problem-based learning reflection, a traditional exercise would be for the student to complete one or more entrepreneurial assessments and then to write a reflection paper on the results.

\section{Discussion of the Technology Enhanced Entrepreneurship Exercise}

One way to enhance the experience from a reflection paper is to capitalize on the use of online journaling via blogging which allows for extensions of having peer students along with those external to the class to review along with comments. By having this in an online journal format, additional assignments can be made where student re-evaluate their progress of increasing their skill sets along with an emphasis of reflection and creating actionable steps to continue progression. The initial blog entry to spur the re- 
evaluation can include the reflection style paper on the results of the entrepreneurial assessment as shown in FIGURE 4. When the utilization of blogs is planned and tied to the learning content, the result is students' apperception of higher degrees of leaning in particular to the content knowledge along with their ability to read, write, and provide feedback via commenting (Garcia, Mozier, Wilkins, \& Haddoud, 2019). Holistically, blogs can be utilized to create a learning environment that promotes continual knowledge improvement by capitalizing on learning gains reflection, self-evaluation, peer engagement, and collaboration -- all of which create a constructivist learning environment (Noel, 2015).

\section{FIGURE 4 \\ BLOG WITH ENTRPRENEURIAL ASSESSMENT EXERCISE REFLECTION BLOG ENTRY}

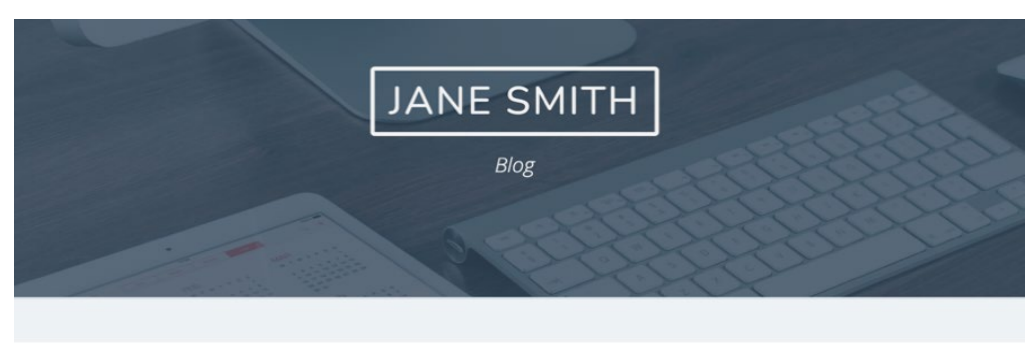

\section{ENTREPRENEURIAL ASSESSMENT EXERCISE REFLECTION}

\section{Exercise 5: Market Research \\ Instructional Strategies}

Business plan and setting up a business.

\section{Importance of Entrepreneurship Exercise}

Engaging in market research helps entrepreneurs to make strategic decision for their product or services identifying key aspects such as price, packaging, product/service name as well as purchasing avenues (Entrepreneur Media, 2014). Knowing one's market is key because $42 \%$ of small businesses' failure was a result of not having a market for their products or services (Johnson, 2020). Entrepreneurs can engage in secondary research (i.e. government databases, articles, websites) or primary research (i.e. interviewing customers directly).

\section{Example of Traditional Entrepreneurship Exercise}

Entrepreneurship students can be asked to include both secondary and primary research on their market to include in their business plan. For the latter, students can check with single customers using surveys or interviews as well as check with several customers in a meeting using focus groups. After asking questions about their product/service, students can compile the customer feedback results, a reflection of what they learned, and revisions they will make in their product/service which can be shared in a paper or presentation. 


\section{Discussion of the Technology Enhanced Entrepreneurship Exercise}

FlipGrid allows for audio and video discussion with threaded relatability similar to commonly utilized text-based discussions in online classes as seen in FIGURE 5. Through the use of a new media platform, discussions utilizing FlipGrid can have the advantage of hearing auditory explanations and seeing visual mannerisms of peers and instructors to make connections of the holistic thought process. This employs the concepts of listen-ability and watch-ability; each entry can be played back in its entirety which gives the advantage of playback-ability (Bower, 2008). FlipGrid not only allows for visual and auditory context, it also permits learning on mobile devices because the FlipGrid technology is made for both laptop/desktop computers, as well as mobile devices which aligns to the technological affordance of the "capacity to be used on various platforms with minimal/ubiquitous underlying technologies" (Bower, 2008, p. 7). When compared to text-based discussions, video-based discussions create environments more effective for social presence among peer students along with a more effective teaching presence of their instructor (Clark, Strudler, \& Grove, 2015). The video-based discussions also promote a connectedness among peers; students enjoy seeing peers' faces which, in turn, indicates that "they experienced lower feelings of isolation when compared with other online courses" (Clark, Strudler, \& Grove, 2015, p. 60).

\section{FIGURE 5}

\section{FLIPGRID INTERFACE}

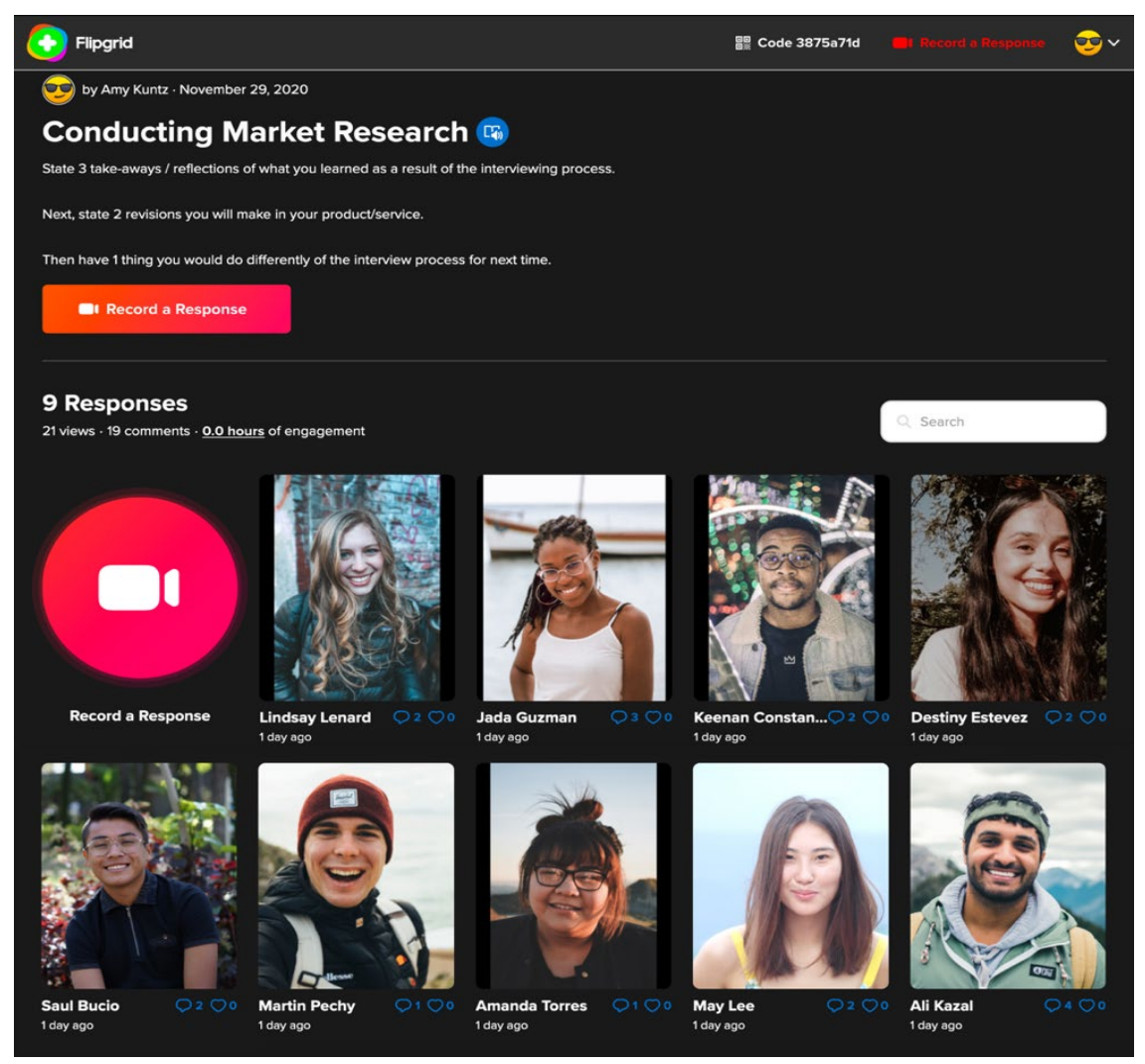

\section{LIMITATIONS}

Numerous types of limitations exist for this study including the response rate (University of Southern California Libraries, 2020). As mentioned earlier, the original intent was to conduct an exploratory study to identify the types of instructional strategies currently being employed in undergraduate online entrepreneurship courses at institutions throughout the United States. This was done by soliciting subjects from online Entrepreneurship faculty in Penn State University's ENTI minor, USASBE, Princeton 
Review's top undergraduate entrepreneurship education undergraduate universities, US News list of top undergraduate business universities, and from the researchers' own searches. However, the response rate was low. The low response rate can be partially attributed to the lower amount of sample size of entrepreneurship degrees or entrepreneurship courses in business degrees offered in an online format with only 25 entrepreneurship programs being offered in a fully-online format (College Navigator, 2020); however, since the study was exploratory in nature, the low response rate was deemed adequate to create a baseline of the types of experiential instructional strategies currently in use.

Another limitation is that the survey results of the types of instructional strategies being utilized in entrepreneurship online courses for baccalaureate students consisted of subjects solicited from mostly a single university. Hence, a subject respondent limitation can exist (Kalof, Dan, \& Detz, 2008).

Financial resources are another limitation (Dudovskiy, 2019). Some financial resources were allocated for this study as participants were given the opportunity to enter a raffle for one of five $\$ 20$ gift cards that were randomly selected after data collection was complete. However, additional financial resources could have been used to offer higher valued prizes or more prizes. Also, additional financial resources could have been utilized to purchase applicable lists of online entrepreneurship faculty. Such financial resources may have had a positive impact on increased and varied participation.

The lack of previous studies on this topic is a limitation (University of Southern California Libraries, 2020). Having numerous prior studies is important such that researchers can have a theoretical foundation to build upon for their study. Additionally, previous studies permit the researchers to have a context for relating their study.

Another limitation is that of timing (Dudovskiy, 2019). Although the research study was emailed at two different times (an initial email and a follow-up email) to subjects, perhaps competing demands caused the timing of such emails to be a limitation. For example, such demands might include advising students for course selection for the next semester, completing writing/submission papers with firm due dates, engaging in critical service project due dates, or preparation for final exams.

A final limitation is that of access to additional technology. The technologies utilized to pair and advance each of the entrepreneurship exercises are instructional technologies that are freely available and utilize hardware devices that are readily available to most learners (i.e. using a computer). Additionally, with all but one technology, edits can be performed on a mobile device such as a phone. Additional possibilities exist to use instructional technologies that have an associated cost as well as hardware such as those on the cutting edge with virtual reality and augmented reality. These can be complementary tools to give students a chance to practice entrepreneurship skills in a virtual environment, low-risk setting (Orel, 2020).

\section{FUTURE RESEARCH}

With the limitations in mind, future research might explore the broader application of entrepreneurshipbased instructional strategies for all online undergraduate business-oriented courses or can be revisited in future years to update the listing because online courses and programs grow. By doing so, a wider sample exists which might increase the response rate.

Another future study could be to compare the utilization of one of the entrepreneurship exercises in the traditional online method to the technology-enhanced method. One course section could employ the traditional online method while the other utilizes the technology-enhanced method. A comparison can be made to explore the quality of comprehension of the material along with student evaluations of the experience. This could then be applied multiple times to address all five types of exercises with a focus of one exercise per course to avoid having competing factors.

Another future area of research could focus on the area of interdisciplinary entrepreneurship education. Numerous universities offer entrepreneurship programs that include students from many diverse areas. For example, St. Mary's University in San Antonio, Texas offers an interdisciplinary E-Scholar program that encompasses these 18 majors "accounting, biochemistry, biology, corporate finance, criminal justice, electrical engineering, engineering management, English communication arts, entrepreneurial studies, 
general business, industrial engineering, international business, international relations, law, and marketing, along with multinational organizational studies in Spanish, political science, and psychology (Johnson \& Envick, 2014, para. 6). If students from diverse disciplines were taking entrepreneurship courses that contained technology-enhanced activities, new research could examine different factors by disciplines such as students' evaluation of the technology-enhanced activities, comfort-level in using technology, comprehension, and quality of completed courses.

A final area of future research can survey students enrolled in online entrepreneurship classes. As mentioned earlier, such faculty shared examples of what they thought were important entrepreneurial exercises within their online classes, though some exercises were not entrepreneurial, and in some instances, any forms of experiential education were absent. In a new study, students could share their perspective to identify which, if any, exercises were deemed to be entrepreneurial which can be compared to the perspective of their instructors.

\section{CONCLUSION}

Kuratko (2005) promulgates the importance for entrepreneur education to be continuously innovative. The use of technology within entrepreneurship education is a popular approach to avoid pedagogical stagnation (Kuratko, 1996; Solomon, 1998). Hence, this paper examined current types of entrepreneurial instructional strategies used with undergraduate students' online entrepreneurship courses and utilized instructional technologies to enhance traditional entrepreneurship strategies. The resulting strategies evolve entrepreneurship education into innovative and experiential learning.

\section{REFERENCES}

Alvord, S.H., Brown, L.D., \& Letts, C.W. (2004). Social entrepreneurship and societal transformation: An exploratory study. The Journal of Applied Behavioral Science, 40(3), 260-282. doi:http://dx.doi.org.ezaccess.libraries.psu.edu/10.1177/0021886304266847

Arpiainen, R., \& Kurczewska, A. (2017). Learning risk-taking and coping with uncertainty through experiential, team-based entrepreneurship education. Industry and Higher Education, 31(3), 143155. doi:10.1177/0950422217700994

Aulet, B. (2013). Disciplined entrepreneurship: 24 steps to a successful startup. Hoboken, NJ.

Baglama, B., Yucesoy, Y., Uzunboylu, H., \& Özcan, D. (2020). Can Infographics facilitate the learning of individuals with mathematical learning difficulties? International Journal of Cognitive Research in Science, Engineering and Education (IJCRSEE), 5(2), 119-128. https://ijcrsee.com/index.php/ijcrsee/article/view/266

Berglund, K., Hytti, U., \& Verduijn, K. (2020). Unsettling entrepreneurship education. Entrepreneurship Education and Pedagogy, 3(3), 208-213. https://doi.org/10.1177/2515127420921480

Bose, R. (2008). Competitive intelligence process and tools for intelligence analysis. Industrial Management \& Data Systems, 108(4), 510-528. doi:http://dx.doi.org.ezaccess.libraries.psu.edu/10.1108/02635570810868362

Bower, M. (2008). Affordance analysis - Matching learning tasks with learning technologies. Educational Media International, 45(1), 3-15. DOI: 10.1080/09523980701847115

Boyle, T.J. (2007). A new model of entrepreneurship education: Implications for central and eastern European universities. Industry and Higher Education, 21(1), 9-19. doi: $10.5367 / 000000007780222688$

Brooks, R., Green, W.S., Hubbard, R.G., Jain, D.C., Katehi, L., McLendon, G., . . Newton, R. (2007). Entrepreneurship in American higher education. Available at SSRN 1291290.

Brown, M., McCormack, M., Reeves, J., Brook, D.C., Grajek, S., Alexander, B., . . Weber, N. (2020). 2020 Educause Horizon Report Teaching and Learning Edition. Louisville, CO: EDUCAUSE. Retrieved from https://www.learntechlib.org/p/215670/ 
Case, S., Coleman, M.S., \& Deshpande, G. (2013). The innovative and entrepreneurial university: Higher education, innovation, and entrepreneurship in focus. US Department of Commerce, Economic Development Administration, Washington.

Christensen, A.K. (2004). Entrepreneurial self-assessment tool. Retrieved from http://centralpt.com/upload/482/sbdc/resourcesarticles/9951_8stepentrepreneurialselfassessment.p $\mathrm{df}$

Clark, C., Strudler, N., \& Grove, K. (2015). Comparing asynchronous and synchronous video vs. text based discussions in an online teacher education course. Online Learning, 19(3), 48-69.

DeMers, J. (2017). Risk or uncertainty: Which is better to face? Entrepreneur. Retrieved from https://www.entrepreneur.com/article/306263

Dudovskiy, J. (2019). Research limitations. Retrieved from https://research-methodology.net/researchmethods/research-limitations/

Duval-Couetil, N. (2013, June). Assessing the impact of entrepreneurship education programs: Challenges and approaches. Journal of Small Business Management, 51(3), 394-409.

Entrepreneur Media. (2014, December 23). Starting a business? 4 ways to research your potential customer. Retrieved from https://www.entrepreneur.com/article/240166

Forrester, J. (1981, January). The use of case studies in pre-experience business education Part II-Using case studies effectively. Vocational Aspect of Education, 33(86), 67.

Garcia, E., Mozier, J., Wilkins, S., \& Haddoud, M.Y. (2019, July). Student learning in higher education through blogging in the classroom. Computers \& Education, 136, 61-74. doi:https://doi.org/10.1016/j.compedu.2019.03.011

Gartner, W.B., \& Vesper, K.H. (1994). Experiments in entrepreneurship education: Successes and failures. Journal of Business Venturing, 9(3), 179-187. doi:10.1016/0883-9026(94)90028-0

Gaytan, J., \& McEwen, B.C. (2007). Effective online instructional and assessment strategies. American Journal of Distance Education, 21(3), 117-132. DOI: 10.1080/08923640701341653

Gibb, A.A. (1996). Entrepreneurship and small business management: Can we afford to neglect them in the twenty-first century business school? British Journal of Management, 7(4), 309-321. doi:10.1111/ j.1467-8551.1996.tb00121.x

Haase, H., \& Lautenschläger, A. (2011). The "teachability dilemma" of entrepreneurship. International Entrepreneurship and Management Journal, 7(2), 145-162. doi:http://dx.doi.org.ezaccess.libraries.psu.edu/10.1007/s11365-010-0150-3

Harrison, R.T., Mason, C.M., \& Girling, P. (2004). Financial bootstrapping and venture development in the software industry. Entrepreneurship \& Regional Development, 16(4), 307-333. https://doiorg.ezaccess.libraries.psu.edu/10.1080/0898562042000263276

Herrington J., Reeves T.C., \& Oliver R. (2014). Authentic learning environments. In J. Spector, M. Merrill, J. Elen, \& M. Bishop (Eds.), Handbook of Research on Educational Communications and Technology. Springer, New York, NY. https://doi.org/10.1007/978-1-4614-3185-5_32

Honig, B. (2004). Entrepreneurship education: Toward a model of contingency-based business planning. Academy of Management Learning \& Education, 3(3), 258-273. doi:10.5465/AMLE.2004.14242112

Humanmetrics. (2020). Entrepreneur quiz. Retrieved from http://www.humanmetrics.com/entrepreneur Imran, T., Ahmed, R.R., Streimikiene, D., Soomro, R.H., Parmar, V., \& Vveinhardt, J. (2019). Assessment of entrepreneurial traits and small-firm performance with entrepreneurial orientation as a mediating Factor. Sustainability, 11(19), 5301. https://doi.org/10.3390/su11195301

Infusion Soft. (2020). What kind of entrepreneur are you? Retrieved from https://quiz.infusionsoft.com/

Jeffrey, S.M., \& Dean, A.S. (2006). Entrepreneurial action and the role of uncertainty in the theory of the entrepreneur. Academy of Management, 31(1), 132-152.

Johnson, J. (2020). A guide to conducting market research. Retrieved from https://www.uschamber.com/co/grow/sales/how-to-conduct-market-research

Johnson, J.E., \& Envick, B.R. (2014). Assessing the learning goal outcome of an interdisciplinary entrepreneurship cohort program: A comprehensive survey approach. Journal of Entrepreneurship Education, 17(1), 135-149. Retrieved from 
http://ezaccess.libraries.psu.edu/login?url=https://www-proquestcom.ezaccess.libraries.psu.edu/scholarly-journals/assessing-learning-goaloutcomes/docview/1645738087/se-2?accountid=13158

Kalof, L., Dan, A., \& Dietz, T. (2008). Essentials of social research. Retrieved from https://ebookcentral.proquest.com

Kek, M., \& Huijser, H. (2017). Towards an ecology for connected learning. DOI: 10.1007/978-981-102454-2_2

Kirzner, L.M. (1973). Competition and entrepreneurship. Chicago, IL: University of Chicago Press. Knight, F. (2921). Risk, uncertainty, and profit. Boston, MA: Houghton Mifflin Co.

Kuratko, D.F. (1996). Risk, challenge \& innovation: The entrepreneurial experience at ball state university. Mid-American Journal of Business, 11(2), 43-48. doi:http://dx.doi.org.ezaccess.libraries.psu.edu/10.1108/19355181199600011

Kuratko, D.F. (2005). The emergence of entrepreneurship education: Development, trends, and challenges. Entrepreneurship Theory and Practice, 29(5), 577-597. https://doi.org/10.1111/j.1540-6520.2005.00099.x

Laukkanen, M. (2000). Exploring alternative approaches in high-level entrepreneurship education: Creating micromechanisms for endogenous regional growth. Entrepreneurship \& Regional Development, 12(1), 25-47. doi:10.1080/089856200283072

Malmström, M. (2014). Typologies of bootstrap financing behavior in small ventures. Venture Capital, 16(1), 27-50. https://doi-org.ezaccess.libraries.psu.edu/10.1080/13691066.2013.863064

Mandel, R., \& Noyes, E. (2016). Survey of experiential entrepreneurship education offerings among top undergraduate entrepreneurship programs. Education+ Training.

McFarland, J., Hussar, B., Wang, X., Zhang, J., Wang, K., Rathbun, A., . . Mann, F.B. (2018). The Condition of Education 2018. NCES 2018-144. National Center for Education Statistics.

McMullan, W.E., \& Gillinm, L.M. (1998). Industrial viewpoint - entrepreneurship education: Developing technological start-up entrepreneurs: A case study of a graduate entrepreneurship programme at Swinburne University. Technovation, 18(4), 275.

More Business. (2020). Business location analysis example - Site selection in business plan. Retrieved from https://www.morebusiness.com/ah_busplanan/

Mwasalwiba, E.S. (2010). Entrepreneurship education: A review of its objectives, teaching methods, and impact indicators. Education \& Training, 52(1), 20-47. doi:http://dx.doi.org.ezaccess.libraries.psu.edu/10.1108/00400911011017663

National Center for Education Statistics. (2010). College navigator.

Neck, H.M., Neck, C.P., \& Murray, E.L. (2017). Entrepreneurship: The practice and mindset. Thousand Oaks, CA: SAGE Publications.

Noel, L. (2015). Using blogs to create a constructivist learning environment. Procedia - Social and Behavioral Sciences, 174, 617-621. doi: 10.1016/j.sbspro.2015.01.591

Okudan, G., \& Rzasa, S. (2006). A project-based approach to entrepreneurial leadership education. Technovation, 26(2), 195-210. doi:10.1016/j.technovation.2004.10.012

Orel, M. (2020). The Potentials of Virtual Reality in Entrepreneurship Education. DOI:10.4324/9781003001874-3

Penn, M.L., Currie, C.S., Hoad, K.A., \& O'Brien, F.A. (2016) The use of case studies in OR teaching. Higher Education Pedagogies, 1(1), 16-25. DOI: 10.1080/23752696.2015.1134201

Peterman, N.E., \& Kennedy, J. (2003). Enterprise education: Influencing students' perceptions of entrepreneurship. Entrepreneurship Theory and Practice, 28(2), 129-144. doi:10.1046/j.15406520.2003.00035.x

Pinchot, G., III. (1985). Intrapreneuring: Why you don 't have to leave the corporation to become an entrepreneur. New York, NY: Harper \& Row.

Powell, B.C. (2013). Dilemmas in entrepreneurship pedagogy. Journal of Entrepreneurship Education, $16(1), 99$.

Rae, D. (1997). Teaching entrepreneurship in Asia: Impact of a pedagogical innovation. Entrepreneurship, Innovation, and Change, 6(3), 193-227. 
Ronstadt, R. (1990). The educated entrepreneurs: A new era of entrepreneurial education is beginning. In C.A. Kent (Ed.), Entrepreneurship education: Current developments, future directions (pp. 6988). New York, NY: Quorum Books.

Rutherford, M.W. (2015). Strategic bootstrapping. Business Expert Press.

Sexton, D.L., \& Bowman, N.B. (1984). Entrepreneurship education: Suggestions for increasing effectiveness. Journal of Small Business Management, 22(2), 18-25.

Small Business Association. (n.d.) Entrepreneurship readiness assessment. Retrieved from https://www.sba.gov/media/training/encore_09012016/story_content/external_files/Readiness\%2 0Assessment.pdf

Solomon, G.T. (1988). Small business management and entrepreneurial education in America: A national survey overview. Journal of Private Enterprise, 4(1), 109-118.

Souitaris, V., Zerbinati, S., \& Al-Laham, A. (2007). Do entrepreneurship programmes raise entrepreneurial intention of science and engineering students? The effect of learning, inspiration and resources. Journal of Business Venturing, 22(4), 566-591. doi:10.1016/j.jbusvent.2006.05.002

Speade, K. (2020). How to find the best location. Entrepreneur. Retrieved from https://www.entrepreneur.com/article/73784

Stevenson, H.H., \& Jarillo, J.C. (1990). A paradigm of entrepreneurship: Entrepreneurial management. Strategic Management Journal, 11(17), 18-27. Retrieved from http://ezaccess.libraries.psu.edu/login?url=https://search-proquestcom.ezaccess.libraries.psu.edu/docview/225014767? accountid $=13158$

Tahmasebifard, H. (2018). The role of competitive intelligence and its sub-types on achieving market performance. Cogent Business \& Management, 5(1). DOI: 10.1080/23311975.2018.1540073

Tarek, B.H., Adel, G., \& Sami, A. (2016). The relationship between "competitive intelligence" and the internationalization of North African SMEs. Competition \& Change, 20(5), 326-336. https://doi.org/10.1177/1024529416657494

Taleo, W., Reedy, A.K., \& Isaias, P. (2019, December). Evaluation of use of VoiceThread for assessment (pp. 302-311). Singapore. Retrieved from https://2019conference.ascilite.org/assets/proceedings/ASCILITE-2019-Proceedings-Final.pdf

University of Southern California Libraries. (2020). Research guides: The discussion. Retrieved from https://libguides.usc.edu/writingguide/limitations

Van Praag, C.M., \& Versloot, P.H. (2007). What is the value of entrepreneurship? A review of recent research. Small Business Economics, 29(4), 351-382.

Yujuico, E. (2008). Connecting the dots in social entrepreneurship through the capabilities approach. Socio-Economic Review, 6(3), 493-513. doi:http://dx.doi.org.ezaccess.libraries.psu.edu/10.1093/ser/mwn003

Zotov, V., Frolova, N., Prasolov, V., \& Kintonova, A. (2020). Case study: An effective technology of modern entrepreneurship education. Journal of Entrepreneurship Education, 23(1), 1-13. Retrieved from http://ezaccess.libraries.psu.edu/login?url=https://www-proquestcom.ezaccess.libraries.psu.edu/scholarly-journals/case-study-effective-technologymodern/docview/2425598834/se-2?accountid=13158 


\section{APPENDIX: PARTICIPATION REQUEST}

\section{Initial Participation Request}

Dear colleague,

We are conducting research with faculty who have taught an online undergraduate Entrepreneurship course. If you are not the applicable person, can you please let us know the proper person we should contact?

Objective: This study seeks to explore the types of instructional strategies currently being employed in undergraduate online entrepreneurship courses at institutions throughout the United States. To that end, this study seeks to answer the following research questions:

- What types of instructional strategies do instructors of undergraduate online entrepreneurship courses report using in their courses?

- Do the instructional strategies reported in online courses reflect established best practices and suggested strategies for teaching entrepreneurship at the undergraduate level?

Results: At the end of this study, we seek to:

- Evaluate the current state of instructional strategies used in online entrepreneurship education at the undergraduate level.

- Compare the use of online strategies to established best practices and recommendations for faceto-face entrepreneurship coursework.

- Establish a set of recommendations for teaching entrepreneurship online at the undergraduate level.

- Establish a vision for future research related to instructional strategies used in online entrepreneurship education.

The survey should take less than 15 minutes. Here is our survey link: https://pennstate.qualtrics.com/jfe/form/SV_3yOeH3L86k8Bt8p

Thank you very much in advance for taking the time to respond to our survey. We appreciate your assistance. If there are any questions, please contact us.

Ellen M. Raineri, Jessica Resig, and Amy Kuntz

Penn State University

\section{Reminder Participation Request}

Dear colleague,

Recently, we sent you an email inviting you to our survey. If you have already responded to the survey, we thank you for your participation. If you have not responded, we invite you to please complete the survey as discussed below. Want to enter a drawing to win $\$ 20$ ?

Your involvement in teaching an online undergraduate entrepreneurship course qualifies you to participate in our study. Upon completing the study, you may elect to enter a drawing to win a $\$ 20$ gift card. Five individual gift card winners will be selected.

We are conducting research with faculty who have taught an online undergraduate Entrepreneurship course. If you are not the applicable person, can you please let us know the proper person we should contact? 
Objective: This study seeks to explore the types of instructional strategies currently being employed in undergraduate online entrepreneurship courses at institutions throughout the United States. To that end, this study seeks to answer the following research questions:

- What types of instructional strategies do instructors of undergraduate online entrepreneurship courses report using in their courses?

- Do the instructional strategies reported in online courses reflect established best practices and suggested strategies for teaching entrepreneurship at the undergraduate level?

Results: At the end of this study, we seek to:

- Evaluate the current state of instructional strategies used in online entrepreneurship education at the undergraduate level.

- Compare the use of online strategies to established best practices and recommendations for faceto-face entrepreneurship coursework.

- Establish a set of recommendations for teaching entrepreneurship online at the undergraduate level.

- Establish a vision for future research related to instructional strategies used in online entrepreneurship education.

The survey should take less than 15 minutes. Here is our survey link:

https://pennstate.qualtrics.com/jfe/form/SV_3yOeH3L86k8Bt8p

Thank you very much in advance for taking the time to respond to our survey. We appreciate your assistance. If there are any questions, please contact us.

Ellen M. Raineri, Jessica Resig, and Amy Kuntz

Penn State University 